\title{
Potentials and Evaluation of Preventive Measures - A Case Study for Germany
}

\author{
Henning Wilts* and Bettina Rademacher
}

Wuppertal Institute for Climate, Environment, Energy $\mathrm{GmbH}$, Research Group Material Flows and Resource Management, Germany

\begin{abstract}
The European Waste Framework Directive has defined waste prevention as top of the waste hierarchy meaning nothing less than a fundamental change of the sociotechnical system of waste infrastructures with all its economic, legal, social and cultural elements. Based on an empirical analysis of more than 300 waste prevention measures this paper assesses which prevention effects can realistically be achieved by applying the measures described in the German waste prevention programme or in those of other EU member states. Taking into account waste streams like packaging, food waste, bulky waste and production waste the results show that waste generation is not an unavoidable evil but can be significantly reduced at current level of technology.
\end{abstract}

Keywords: Waste prevention; Food waste; Production waste, Packaging waste, Eco-innovations

\section{Introduction}

Waste prevention as highest priority of the waste hierarchy - as confirmed by the revised Waste Framework Directive 2008/98/EG - is more than just a simple amendment of the way waste is dealt with. This definition means nothing less than a fundamental change of the sociotechnical system of waste infrastructures with all its economic, legal, social and cultural elements [1]. Essentially, this is also associated with the transition from end-of-pipe technologies to an integrated resource management [2]. Considering the dimension and the complexity of such a task, it is not surprising that up to now waste prevention as a policy approach played only a minor role within the European Union [3]. Therefore, the Waste Framework Directive obliges member states to develop national waste prevention programmes as a policy instrument.

In Germany, a research project that was funded by the Federal Ministry of the Environment and the Federal Environment Agency developed scientific and technical foundations for a national waste prevention programme [4].

The project has collected and analysed a great number of measures within the public sector in Germany, which already assist in preventing waste generation. Thereby, the analysis focused on public measures but still considered legal framework conditions and economic incentives for private prevention measures. The German case studies are supplemented by specific measures from other countries or measures derived from literature in order to build a foundatio for the national prevention programme. On the basis of these results, generic instruments have been developed as possible elements of the German waste prevention programme in a second research project with the involvement of the federal states [5].

Accounting for these activities, a trivial question soon comes up: Which prevention effects can realistically be achieved by applying the measures described in the waste prevention programme of the federal government or other member states? Isn't the generation of waste unavoidable to a great extent? [6].

A current study on behalf of the European Commission estimates the waste prevention potential at $4 \%$, given that all waste legislation guidelines are adopted by the year 2020. But why does such a low number result, which tempts to consider waste prevention rather a minor addition instead of a top priority in the waste hierarchy? In this regard, the study states the following.

Experience with cleaner production centres in Germany has shown, that some $8 \%$ of waste generation can be prevented by supporting the enterprises through audit, consulting and financing schemes. It is assumed that this $8 \%$ are a typical waste prevention potential for all waste types. It is further assumed that half of this potential can be activated by the new waste prevention measures till 2020 [7].

This assumption can be discussed in many respects, which is in the nature of assumptions. Nevertheless it is tried hereafter to demonstrate potentials that could be obtained through intelligent waste prevention concepts on the basis of individual waste streams. Naturally, even these results can't always be transferred 1:1. Still they make clear, that especially comprehensive approaches through the value chain can enable the successful reconsideration of waste generation, which meanwhile already has become accepted as a necessary evil.

\section{Potentials and Successes in Prevention}

In principle, statements concerning prevention potentials and successes are confronted with the general problem of trying to measure something which has not yet accrued. At the same time, the generation of waste correlates strongly with economic growth, so that decreasing amounts of waste often rather indicate economic crises than successes in prevention.

Meanwhile, a variety of studies exist for waste streams like packaging, food waste, bulky waste and production waste, which on the one hand present information about the potential of waste prevention, and on the other hand also suggest specific measures which could be associated with a specific prevention success. These waste streams

*Corresponding author: Henning Wilts, Wuppertal Institute for Climate, Environment,Energy $\mathrm{GmbH}$, Research Group Material Flows and Resource Management, Germany, Tel: +49 202 2492-290; Fax: +49 202 2492-138; E-mail: henning.wilts@wupperinst.org

Received January 09, 2014; Accepted February 20, 2014; Published February 27, 2014

Citation: Wilts H, Rademacher B (2014) Potentials and Evaluation of Preventive Measures - A Case Study for Germany. Int J Waste Resources 4: 137. doi: 10.4172/2252-5211.1000137

Copyright: (c) 2014 Wilts $\mathrm{H}$, et al. This is an open-access article distributed under the terms of the Creative Commons Attribution License, which permits unrestricted use, distribution, and reproduction in any medium, provided the original author and source are credited. 
have been chosen for the purpose of this paper because they show the broad range of different kinds of waste especially with regard to their heterogenity and economic incentives for recovery.

\section{Packaging waste}

For some time packaging wastes, especially plastic bags, have been focused by the public debate about waste prevention. For example, a current press release says: "The issue of plastic bags is crucial in the debate on sustainable consumption, the need for a close-loop recycling society and the need to act against litter. "The foreground isn't so much occupied by the actual quantitative or ecological significance of this waste stream, but rather by its perception as symbol of a throwaway society [8]. Of the overall amount of waste arising in German households, which is about 40 Million tons, packaging has only a share of about 7\% [9]. At the same time, the average usage time of a plastic bag amounts to 25 minutes [10]. Similarly, packaging is also often thrown away immediately after opening.

Particularly interesting here is taking a look at Great Britain, where the prevention of packaging wastes is a central point of the Waste and Resources Action Programme (WRAP). As part of the campagne ,Courtauld Commitment', which was initiated in 2005, the nongovernmental organization cooperates with grocers, brand owners and producers in order to reduce the impacts of the food industry on climate and environment. The first phase of the Courtald Commitment was already joined by more than 40 larger retailers, brand owners, manufacturers and producers, which in total represented $92 \%$ of food trade in Great Britain (the programme is divided into three integrative phases, whereas phase 3 commenced in 2013). These made a commitment, amongst other things, to avoid the increase of packaging waste generation completely until the end of 2008, and to achieve an absolute decrease until 2010 [11]. In the course of the project, packaging wastes were aimed to be reduced through design optimization primarily. For this reason, new packaging strategies for implementation within the whole supply chain have been developed. The applied measures for innovation and improvement of packaged products include [12]:

- Decoating

- Weight reduction

- Use of recycled materials

- New conception of product use, e.g. refillable bottles, design for recyclability

\section{- Reduction of food wastes}

- Support of increased collection for reuse

- Import of large quantities (e.g. wine for bottling in Great Britain)

- Improved supply chain and transport efficiencies

Table 1 shows the saving potentials for packaging calculated by WRAP. These could be achieved without new technical developments, but solely by application of the best packaging solution currently available for various products.

Since 2008, the average amount of packaging of every grocery purchased in Gerat Britain has decreased by approximately $4 \%$ (however, an absolute reduction has been missed so far, considering a significant increase in overall food sales) [14]. Still a series of specific case studies clarifies the ecological and economic saving potential in the area of packaging waste, which can be attained through intelligent concepts.
Cadbury: It is a leading member of the resource efficiency initiative ,Seasonal Confectionery Working Group' (SCWG) established by the industry. In 2009, the company took further steps towards reducing its environmental impacts by reducing the packaging of their Easter Eggs. In cooperation with WRAP, a $25 \%$ reduction in packaging of their medium eggs has been achieved, which in turn reduced material consumption by 220 tonnes of plastic, 250 tons of cardboard and 90 tons of transport and display packaging. Concerning the large eggs, packaging has also been reduced by $30 \%$, which saved 108 tons of plastic, 65 tons of cardboard and 44 tons of corrugated cardboard. In 2008, the Cadbury, Eco Eggs'-series received an award for best packaging at the, Green Awards'.

Apetito: It is a supplier of high-qualitative frozen food and catering solutions, supplying a wide range of community meals to local authorities and franchise dealers who distribute to individuals in their own home through their meals on wheels service. Together with their employees, the company supports WRAP's Love Food Hate Waste inititiative for the reduction of food wastes by using food optimally in the workspace and by sharing information with employees via their company newsletter ,Team News'. In this way, cost savings have been achieved by less waste, labelling, freezing, usage of long lasting products, portioning and the use-up of leftovers. Further cost reductions resulted from improved protection of groceries, storing capacities and transport. In total, apetito saves approximately 112 tons of cardboard per year and thereby avoids about 230 tons of $\mathrm{CO}_{2}$ [12].

\section{Food waste}

The prevention of food wastes can be seen as one of the most promising while also most urgent areas of waste prevention. In Germany alone, food waste represents a quarter of all waste arising in households [9]. According to a report „Global Food Losses and Food Waste" published by the FAO, about 1,2 billion tons of food wastes are produced annually. In the European Union, losses along the food chain amount to 280-300 € per capita and year; a quantity which makes up the overall food supply in sub-Saharan Africa. Taking into account the high resource intensity of the food sector, the European Commission has defined the goal of reducing the production of food wastes by $50 \%$ until 2020 within the framework of the „Roadmap for a resource efficient Europe". As a matter of fact, a variety of research projects has already proven this goal to be achievable $[4,5]$. However, there is

\begin{tabular}{|c|c|c|c|}
\hline & Product Category & $\begin{array}{c}\text { Packaging Weight (in } \\
\text { tons) }\end{array}$ & $\begin{array}{c}\text { Saving Potential (in } \\
\text { tons) }\end{array}$ \\
\hline 1 & wine (bottles) & 472,296 & 120,000 \\
\hline 2 & convenience foods (frozen) & 30,678 & 19,660 \\
\hline 3 & soft drinks (cans) & 47,725 & 16,903 \\
\hline 4 & beer (cans) & 46,728 & 15,545 \\
\hline 5 & pizza (frozen) & 20,344 & 13,568 \\
\hline 6 & beer (bottles) & 87,470 & 13,254 \\
\hline 7 & whisky (bottles) & 58,448 & 12,758 \\
\hline 8 & ready-made sauces (jars) & 106,752 & 12,152 \\
\hline 9 & fruit juice (cartons) & 51,144 & 10,283 \\
\hline 10 & pet food (cans) & 80,971 & 9,212 \\
\hline 11 & soft drinks (plastic bottles) & 74,218 & 8,833 \\
\hline 12 & ketchup & 21,222 & 7,720 \\
\hline 13 & milk (cartons) & 12,876 & 7,433 \\
\hline 14 & eggs (tablet and box) & 12,854 & 6,697 \\
\hline 15 & vodka (bottles) & 27,048 & 6,273 \\
\hline & TOTAL & $\mathbf{1 , 1 5 0 , 8 2 9}$ & $\mathbf{2 8 0 , 2 9 1}$ \\
\hline
\end{tabular}

Table 1: Waste prevention potentials obtained through the best design solution available on the UK market in 2004 [13]. 
a need to realize this goal on the basis of systemic approaches, taking into account the whole food chain, including agriculture, processors, dealers and consumers

In Great Britain, a study with the goal of quantifying prevention potentials of food waste revealed that about two thirds of the total 8.3 million tons of food waste would have been avoidable (disposed of groceries which would have been enjoyable earlier). Furthermore, about half of the remaining 3 million tons have been potentially avoidable (groceries which some people consume and others don't, e.g. potato peelings). Besides this, the study comes to the conclusion that in case of complete prevention of the share of clearly avoidable wastes, a monetary saving of 12 billion pounds could have been achieved. Additionally, a saving ot 20 million tons carbon dioxide per year would have been the result, about $2.4 \%$ of greenhouse gas emissions caused by consumption in Great Britain. For Germany, the study "Ermittlung der weggeworfenen Lebensmittelmengen und Vorschläge zur Verminderung der Wegwerfrate bei Lebensmitteln in Deutschland" calculates a total amount of 10,970,000 tons disposed of groceries per year, taking into account every stage of the of the value chain [15]. Hereby the the largest part is made up by households, which are mainly responsible for food waste with $61 \%$. Bulk consumers and industry contribute with $17 \%$ each, retail trade with $5 \%$. In households, amongst other things the small share of total consumption expenses for food and the permanent availability of groceries are mentioned as causes for a decreasing appreciation of groceries.

The detection of the above mentioned potentials with regard to waste prevention forms the basis of the WRAP campaign, Love Food Hate Waste', which was initiated in 2007 and targets the reduction of food wastes in private households. For this purpose, the programme cooperates with traders and manufacturers on the one hand, to support those in developing individual respective campaigns. On the other hand, it aims at raising the attention of individuals in order to increase their sensitivity towards the issue of food waste. In this way, the british supermarket chains Sainsbury's and Morrison's, for example, introduced an improved labelling system for best-before dates and installed packaging sizes which enable modern households to be more flexible in the purchase and consumption of groceries [16]. At the same time, ,Love Food Hate Waste' supplies consumers with practical advice and incentives for using their groceries in the best possible way. This e.g. regards easily acquirable habits of waste reduction, which besides the reduction of environmental impacts also result in significant cost savings for consumers. The acquired habits include the preparation of shopping lists and meal planning as well as freezing products with limited shelf life, appropriate product storage and the creative use-up of leftovers.

During a renewed calculation of food waste amounts in british households in 2011, WRAP could already record a decrease [17]. By means of a comparison of statistical purchase data from the years 2006 to 2009 , the reduction of potentially avoidable or unavoidable waste is estimated at 73,000 tons and 77,000 tons respectively. Concerning the overall traceable reduction of 1.1 million tons (13\% of food waste in households), this implies a decrease of avoidable food wastes by 950,000 tons. These numbers are further confirmed by two studies, which both quantified the share of food wastes of household wastes in England. For this purpose, information from the WasteDataFlow as well as existing compositinal analyses have been consulted. The first study was conducted in 2006/07, the second one in 2008 [18]. The estimations from this studies indicate a significant reduction of food wastes in households within the investigated period. Taking the lowest determined number, the decline was $13.1 \%$ in comparison to the number of 2006/07 [19].

In order to be able to document changes in behaviour of consumers, WRAP additionaly collected questionnaires giving information about the behaviour of private households regarding three measures: The checkup of stocks before shopping, the planning of meals over several days and the preparation of shopping lists. On this occasion, an increase by 3 to 5 percentage points of all three behaviour patterns could be registered until 2010. Moreover, the understanding of best-before dates was improved, which could also have contributed to the prevention of wastes. In a consumer survey of the "Food and Drink Federation" with more than 1000 respondents in the same year, more than half of the respondents reported to dispose less groceries than the year before.

\section{Bulky waste and used electric and electronic equipment}

Bulky waste currently accounts for about $6 \%$ of the waste which is generated in households [9]. For used electronic equipment, there is no current data, but in 2005 their proportion amounted to a little less than $1 \%$ [20]. While percentage may appear small, it is still significant in view of a number of hazardous chemicals and precious resources used in the production process of these devices. With a view to the issues waste and circular economy, directive 2008/98/EG (EU Waste Framework Directive, short: WFD) requires member states to step up their efforts, especially in terms of reuse, according to the new 5-stage waste hierarchy. Article 11 obliges the member states to take suitable measures for the promotion of reuse and reparature of products, while at the same time mentioning possible measures, i.a. explicitly the installation and support of reparature and reuse networks.

In reality, reparature and reuse of used products has become considerably less important over the last decades. A few reasons for this are the increased complexity of mostly electronic products just as the increasingly shorter innovation cycles, which lead to a rapid depreciation in value of products. Besides, it becomes clear however that the reuse of products is additionally complicated by a conscious deterioration of product qualities (keyword planned obsolescence) [21].

In spite of this, various european regions have succeeded in making relevant amounts of wastes reusable and in placing the reuse of products in public awareness. These examples prove, that reuse is possible despite the prevailing given circumstances!

In Flanders, for example, reusable items are further used via the Kringloop network under the brand "De Kringwinkel". The network essentially consists of the flemish umbrella organization Komosie, reuse centres and De Kringwinkel shops. In total, the organizations operate about 118 shops (state: 2011) in which second hand products are sold. The range of products covers all potentially reusable products (WEEE, clothing, furniture, etc.) collected from households. Cooperations between the reuse centres, waste management and Recupel - the collective collection system of Waste electric and electronic equipment - enable a structured access to products. A reuse quota of $47 \%(4.41$ $\mathrm{kg}$ per inhabitant) of collected products is already achieved, which amounts to an increase of more than $1,000 \%$ since 1994. Until 2015, the aim is to achieve a reuse quota of $5 \mathrm{~kg}$ per inhabitant and employment of 3,000 full-time employees.

An further impressive example are the so called Repair Cafés, which first took place in 2009 in the Netherlands. Repair Cafés are events in which reparature experts and consumers with broken items come together and repair those together over coffee and tea. The organization of the events, just as the engagement of the experts is based on voluntary 
activities, participation is generally free. On average, 25 products are repaired each Repair Café and month. Currently there are 21 Repair Cafés in Germany, in which 6,300 products are repaired annually. In total, about $70 \%$ of devices and products which are brought along by the participants can be repaired [22].

\section{Commercial waste}

The overall number of waste generated in Germany amounted to about 387 Million tons in the year 2011 [23]. Waste from industry and production accounted for $15.1 \%$ of this number. Operational cost savings through prevention of wastes are a much - discussed topic in Germany, at the latest since the requirements of the 5.1.3 BlmSchG in the 1990ies. Within the framework of an investigation of environmental management systems in Germany, almost $80 \%$ of the participating enterprises already reported to have exploited potentials in the area of waste prevention. On a scale between $1=$ high significance and $6=$ low significance, effects in this area were even awarded with the highest significance. However it can be observed that high waste prevention potentials are still undetected, primarily in cooperation along the value chain [5]. Here, many intersections arise with the issue of material efficiency in the industrial sector. Every prevented material input finally results in a prevention of wastes - be that during raw material extraction, in the industry itself or at the consumption stage.

A study of the Fraunhofer ISI reports that according to assessment of the enterprises themselves, within the current technical standards (!) approximately $7 \%$ of material consumption could be saved. In the automobile sector, this estimation even amounts to 10\% [24]. By optimizing efficiency consulting of enterprises with regard to waste prevention, cost saving potentials could be traced, especially in the manufacturing industry, which on the one hand lead to increased resource efficiency and on the other hand offer a monetary incentive for businesses to realize regarding measures. Efficiency consulting of this kind could take up existing programmes, amongst others that of the German Material Efficiency Agency (demea), while it is also supposed to obtain more realization potential by additional training and mediation of 'bridge qualifications' to consultants. It is assumed that the realization of the recommended measures, with regard to technical progress until 2016, could save one fifth of all raw materials used in production. This relates to quantitative raw materials savings of 300 million tons per year [25].

An extension of this promising measure whose effects are also significant but haven't been quantifiable up until now is the extension of existing web-based consultation offers with the aspect of purchasing low-waste and low-emission raw materials. The consideration of environmental and waste criteria in the purchase of raw materials could be specifically promoted by governmental bodies. In this way, enterprises could be sensitised for the environmental impacts outside of their own business as well as expand their knowledge about possibilities of a low-waste material purchase. Waste-minimizing cooperations in value chains are another potential approach of waste prevention. In real supply chains, interface problems are often "bridged" in a way that leads to waste generation. One example of this is the conscious delivery of logistical supersets to guarantee $100 \%$-availability at the point of sale. By means of a systematic cooperation of all partners of a value chain, potentials for the reduction of material losses resulting from interface arrangements, unnecessary or wrong specifications or logistical requirements could be identified which wouldn't be manageable for a single actor. Especially the addition of waste issues to optimized logistical planning within the supply chain cooperation could lead to relevant waste prevention potentials, according to expert opinions. In product segments which feature high rates of remittances, such as fashion, magazines or even groceries, saving potentials are estimated to be a double-digit percentage.

A study named "Study on the design of a program for increasing material efficiency in SMEs" and conducted by author D. Little in cooperation with the Fraunhofer Institute and the Wuppertal Institute shows, that waste prevention through material efficiency can also involve significant monetary saving potentials.

The manufacture of fabricated metal products, for example, is done mainly with production techniques that have been used for decades. Even in the future, no major changes are expected in this regard. Improvements of material efficiency could be achieved through material know-how and calculation methods which lead to a more material efficient design of products and manufacturing processes, such as e.g. automated manufacturing and continuous quality control during operation. New tool materials can reduce wear and tear and the dry process of machining production can save a subsequent cleaning process including auxiliaries and thermal heating. A high number of small enterprises with high shares of material cost and relatively high saving potentials make the manufacture of fabricated metal products appear to be a promising branch for the increase of material efficiency. The potential is estimated at 800 to 1,500 million $€$ in 2012-15.

Within the framwork of a study named "Study on reinforced waste prevention in the commercial sector" conducted by the Bavarian State Ministry for the Environment, Public Health and Consumer Protection, measure concepts of company-specific approaches for reduction and utilization of waste have been introduced in cooperation with pilot enterprises of different sectors [26]. For the sector of machine tools, metal products and metal working, saving potentials of $131.2 \mathrm{~kg}$ prevented waste per employee and year resulted. Additionally, 87.2 $\mathrm{kg}$ per employee could be recycled. With 499,000 employees in whole Germany, a theoretical prevention potential of 65,468 tons per year and a recycling potential of 43,512 tons per year can be calculated for this sector only, assuming that the measures from the pilot enterprises were realized in every german business [27].

In total, the nine sectors which were analysed within the framework of the study exhibit saving potenials between 6.4 billion $€ / \mathrm{a}$ and 13 billion $€ / \mathrm{a}$ through the increase of material efficiency. For the manufacturing industry, the estimate is about 27 billion $€ / a$ (for autonomous material specific and technical progress) and up to almost 60 billion $€ / a$ within the years $2012-2015$ as policy-inducible potential [28]

\section{Total Potentials and Approaches of Priorisation}

In the overall debate about waste prevention, it is striking up to now that in the face of a variety of suggested measures or realized individual projects, no clear concept seems to exist so far concerning the priorisation of a starting point. Often, focal points seem to be determined primarily through public discussion of individual waste streams (cell phones, plastic bags, old clothes..). With a view to limited public funds, approaches which determine multi-sectoral prevention potentials for all waste streams seem necessary.

A first useful point of reference from the perspective of waste prevention is the consideration of ecological backpacks. These specify the amount of natural resources used for different consumption goods. "The more nature has been put into a consumption good, the heavier is its ecological backpack". Essential is the fact that in order to calculate the weight declarations of the ecological backpack, the whole life cycle of a consumption good is taken into consideration [29]: 
Citation: Wilts H, Rademacher B (2014) Potentials and Evaluation of Preventive Measures - A Case Study for Germany. Int J Waste Resources 4: 137. doi: $10.4172 / 2252-5211.1000137$

Page 5 of 7

- From raw material production and manufacturing (including extraction, production of pre-products, transport and sale)

- To utilization (including all consumption, transports and reparatures)

- Up to recycling or reuse.

This consideration focusses on resource input, which is extracted from nature. Because of the fact that material doesn't "vanish", it is obvious, that every input into the system has to end up as waste at some point. The consideration of ecological backpacks is therefore a well suitable indicator to carry out a first priorisation which products waste prevention should concentrate on. It gives information about the consumption of natural resources of a product. The more resources a product requires, the heavier its ecological backpack gets. This includes resources used along the whole life cycle of a product, from raw material extraction to use phase and disposal or recycling. Table 2 gives a selected number of examples of products with their specific ecological backpacks.

Another, product-related approach is the question, for which products optimizations of product design and production processes can result in environmental reliefs. In the course of the discussion about an extension of the ecodesign guideline to questions of energy consumption, a study presented by BioIS identified products and product categories for which the ecodesign guideline could deduce potentials for ecological improvements. For this purpose, 60 product categories in total have been investigated for all of their environmental impacts. Table 3 shows the product categories for which a particularly high ecodesign-potential has been determined according to a review of existing life cycle assessments.

\section{Conclusions}

The analysis of the herein considered waste streams makes clear that there are still high unexploited potentials in the prevention of waste under existing technical and institutional circumstances. Even for the automobile sector, which is generally regarded to be very costsensitive, practicians deem a saving potential of more than $10 \%$ of used materials realistic, which would become visible in waste prevention

\begin{tabular}{|c|c|}
\hline Product & Ecological Backpack \\
\hline bedstead & $666 \mathrm{~kg}$ \\
\hline sofa (3 seats) & $694 \mathrm{~kg}$ \\
\hline desk & $272 \mathrm{~kg}$ \\
\hline combination fridge/freezer & $2381 \mathrm{~kg}$ \\
\hline washing machine & $1215 \mathrm{~kg}$ \\
\hline LCD TV & $2666 \mathrm{~kg}$ \\
\hline laptop & $743 \mathrm{~kg}$ \\
\hline cell phone & $44 \mathrm{~kg}$ \\
\hline fleece jacket & $9.1 \mathrm{~kg}$ \\
\hline aluminium foil (20 meters) & $4.8 \mathrm{~kg}$ \\
\hline recycled paper (100 sheet) & $15 \mathrm{~kg}$ \\
\hline plastic foil (20 meters) & $0.34 \mathrm{~kg}$ \\
\hline vacuum cleaner & $84 \mathrm{~kg}$ \\
\hline DVD player & $1928 \mathrm{~kg}$ \\
\hline jeans & $6.8 \mathrm{~kg}$ \\
\hline t-shirt & $16 \mathrm{~kg}$ \\
\hline
\end{tabular}

Table 2: Ecological backpacks of selected examples [29]. of mainly enterprises. The area of food waste also shows that simple measures could already result in more than $10 \%$ savings.

Taking into account the area of reuse of waste electronics, successful reuse networks can be found which already feature quotas more than a factor 10 above the german average. A particular case in Germany is certainly packaging waste, which already demonstrated incentives for reducing packaging because of high license fees during the monopoly stage of 'Der Grüne Punkt'. This example also clarifies that economic incentive instruments show potentials, especially for enterprises, to contribute to waste prevention. Even more tragic, against this background, appears the current situation on the german incineration market, where spot prices around $30 €$ per ton certainly don't induce many companies to invest in waste preventing technologies or processes at the moment. Figure 1 gives an overview over the price differences between spot and contract prices for commercial waste as well as municipal waste disposal prices for incineration in different areas of Germany.

Furthermore, the consideration shows that the initial question "How much waste could be prevented?" can only be answered for short time periods. The consulted studies allow the conclusion, that about $10-15 \%$ of all wastes within a year could be prevented - even if drastic legal specifications (principally conceivable would be e.g. the prohibition of particularly waste intensive products via the ecodesign guideline analogous to light bulbs) or financial incentives (e.g. an additional tax on waste incineration as it already existits in various EU member states) were omitted.

However, changes in product design, in used raw materials or useful life will only be effective medium-to-long term. On the other hand, systemic approaches such as the "share economy" or the "leasing society" as frontrunners of a fundamental change in consumptions patterns and a new relationship between wealth and product possession present potentials that make at least a halving of all generated waste seem realistic $[30,31]$. Further research will be needed to analyze long term effects of specific innovations, processes or technologies with regard to their waste prevention potentials. Especially an integrated assessment of environmental and ecologic saving potentials will be necessary in order to trigger further eco-innovations and to allow an efficient allocation of benefits between the different actors in the value chain.

\begin{tabular}{|l|l|}
\hline \multicolumn{2}{|c|}{ Product } \\
\hline AV devices & Motors (ICE) \\
\hline Batteries & Hand tools \\
\hline Computer related & Furniture \\
\hline Office equipment & Household goods \\
\hline Power tools & Paper packaging \\
\hline Detectors & Hygiene papers \\
\hline Other electronics & Paper goods, tablets and related \\
\hline pardening tools & Products \\
\hline Heating & Fersonal road transport \\
\hline Household devices & Motorbikes, bicycles \\
\hline Print & Rail transport \\
\hline
\end{tabular}

Table 3: Most Important Product Categories for the Evaluation of the Ecodesign Instrument as Policy Approach [7]. 
Citation: Wilts H, Rademacher B (2014) Potentials and Evaluation of Preventive Measures - A Case Study for Germany. Int J Waste Resources 4: 137. doi: $10.4172 / 2252-5211.1000137$

Page 6 of 7

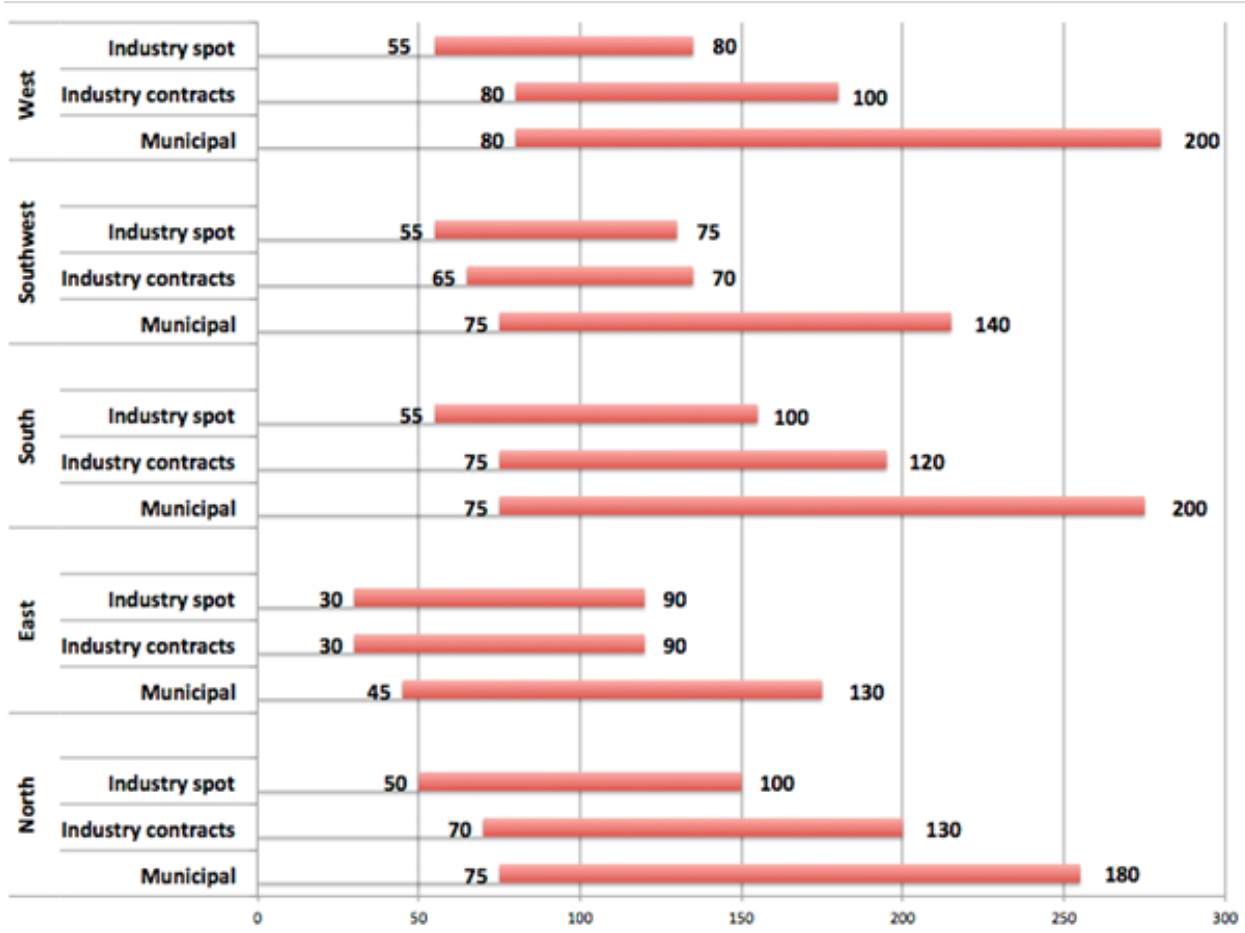

Figure 1: Prices and Fees in Incinerators in Germany, Nov./ Dec. 2012 [22]

\section{References}

1. Berkhout F, Smith A, Stirling A (2003) Socio-technological regimes and transition contexts. SPRU Electronic Working Paper No. 106. Brighton.

2. ISWA Working Group on Recycling and Waste Minimization (2011) ISWA Key Issue Paper on Waste Prevention Waste Minimization and Resource Management. Vienna.

3. Gentil EC, Gallo D, Christensen TH (2011) Environmental evaluation of municipal waste prevention. Waste Management. 31: 2371-2379.

4. Dehoust G, Küppers $P$, Bringezu S, Wilts H (2010) Development of scientific and technical foundations for a national waste prevention programme. Environmental Research Programme of the Federal Ministry for the Environment, Nature Conservation and Nuclear Safety. On behalf of the Federal Environment Agency.

5. Dehoust G, Jepsen D, Knappe F, Wilts H (2012) Substantive implementation of Article 29 of Directive 2008/98/EC. Scientific technical foundation for a national waste prevention program. Final Report. Environmental Research Programme of the Federal Ministry for the Environment, Nature Conservation and Nuclear Safety.On behalf oft he Federal Environment Agency.

6. Wilts H, Dehoust G, Jepsen D, Knappe F (2013) Eco-innovations for waste prevention-Best practices, drivers and barriers. Science of the Total Environment. 461: 823-829.

7. BIO Intelligence Service (2011) Implementing EU Waste Legislation for Green Growth. Final Report. On behalf of the European Commission DG ENV. Paris.

8. ACR Plus (2013) Plastic bags: an analysis of policy options and instruments.

9. Destatis (2013) Waste Environment. Fachserie 19. Reihe 1. Wiesbaden.

10. Robin Wood (2010) Colorful and dangerous - Robin Wood. Issue 104: 8-9

11. WRAP (2013) Courtauld Commitment 2.

12. WRAP (2012) Courtauld Commitment 2. Signatory case studies and quotes.

13. WRAP (2007) Understanding Food Waste. Key findings of our recent research on the nature, scale and causes of household food waste.

14. WRAP (2013) Courtauld Commitment 1
15. Kranert M, Hafner G, Barabosz J, Schuller H, Leverenz D, et al. (2012) Ermittlung der weggeworfenen Lebensmittelmengen und Vorschläge zur Verminderung der Wegwerfrate bei Lebensmitteln in Deutschland. Institut für Siedlungswasserbau, Wassergüte- und Abfallwirtschaft. Stuttgart.

16. WRAP (2010) Love Food Hate Waste. An Introduction

17. WRAP (2011) New estimates for household food and drink waste in the UK.

18. DEFRA (2008) Review of Municipal Waste Component Analyses. Resource Futures for Defra.

19. WRAP (2010) Evaluation of Courtauld Food Waste Target - Phase 1.

20. Schridde S, Kreiß C (2013) Geplante Obsoleszenz. Report on behalf of the Bundesfraktion Bündnis 90/ Die Grünen. Berlin.

21. Destatis (2007) Waste Environment.Fachserie 19. Reihe 1. Wiesbaden.

22. Wilts H, Gries N (2013) Reuse - One Step Beyond. Feasibility Study Wuppertal

23. Destatis (2013) waste arise in Germany at 387 million tonnes.

24. Schroter M, Lerch C, Jäger A (2011) Material efficiency in production: savings and dissemination of concepts for saving materials in manufacturing.. Final Report to the an das Federal Ministry of Economics and Technology (BMWi). Fraunhofer Institute for Systems and Innovation Research (ISI). Karlsruhe.

25. BMU (2012) Federal Ministry for the Environment, Nature Conservation and Nuclear Safety. GreenTech made in Germany 3.0. Umwelttechnologie-Atlas für Deutschland. Berlin.

26. StMUGV (2005) Bavarian state ministry of the environment, health and consumer protection.

27. Destatis (2013) Federal Office of Statistics. May 2013: 0.6\% more employees in manufacturing.

28. Baron R, Alberti K, Gerber J, Jochem E, Bradke H, et al. (2011) Study on the design of a program for the improvement of material efficiency in mittelständischen company.

29. Federal Ministry of Education and Research (BMBF) (2012) Commodity expedition. The ecological rucksack. 
Citation: Wilts H, Rademacher B (2014) Potentials and Evaluation of Preventive Measures - A Case Study for Germany. Int J Waste Resources 4: 137. doi: $10.4172 / 2252-5211.1000137$

Page 7 of 7

30. Heinrichs H, Grunenberg H. (2013) Sharing Economy: Towards a New Culture of Consumption? Centre for Sustainability Management Luneburg.

31. Fischer S, Steger S, Jordan ND, O’Brien M, Schepelmann P (2012) Leasing Society: Study. Brussels.
32. WRAP (2009) Household Food and Drink Waste in the UK. Final Report Banbury.

33. WRAP (2011) The Courtauld Commitment Phase 2. First Year Progress Report Banbury.
Citation: Wilts H, Rademacher B (2014) Potentials and Evaluation of Preventive Measures - A Case Study for Germany. Int J Waste Resources 4: 137. doi: $10.4172 / 2252-5211.1000137$
Submit your next manuscript and get advantages of OMICS Group submissions

\section{Unique features:}

User friendly/feasible website-translation of your paper to 50 world's leading languages

Audio Version of published paper

Digital articles to share and explore

Special features:

300 Open Access Journals

25,000 editorial team

21 days rapid review process

Quality and quick editorial, review and publication processing

Indexing at PubMed (partial), Scopus, EBSCO, Index Copernicus and Google Scholar etc

Sharing Option: Social Networking Enabled

Authors, Reviewers and Editors rewarded with online Scientific Credits

Better discount for your subsequent articles

Submit your manuscript at: hitp://www.omicsgroup.info/editorialtracking/waste-resources/SubmitManuscript.php 